\title{
Комбинационное рассеяние света полупроводниковых структур с нанометровым пространственным разрешением
}

\author{
А.Г. Милехин ${ }^{1,2}$, Н.Н. Курусь ${ }^{1}$, Л.С. Басалаева ${ }^{1}$, К.В. Аникин ${ }^{1}$, Т.А. Дуда ${ }^{1}$, Е.Е. Родякина ${ }^{1,2}$, Р.Б. \\ Васильев $^{3}$, I.A. Milekhin ${ }^{4}$, M. Rahaman ${ }^{4}$, D.R.T. Zahn" ${ }^{4}$, A.B. Латышев ${ }^{1,2}$ \\ ${ }^{1}$ Институт физики полупроводников им. А.В. Ржанова СО РАН, \\ Новосибирск, 630090, пр. ак. Лаврентьева, 13 \\ ${ }^{2}$ Новосибирский государственный университет, 630090, Пирогова \\ ${ }^{3}$ Московский государственный университет им. М.В. Ломоносова, Москва, 119991, \\ Ленинские горы, 1 \\ ${ }^{4}$ Semiconductor Physics, Chemnitz University of Technology, D-09107 Chemnitz, Germany \\ тел: +7 (383) 330-8204, факс: +7 (383)333-2771, эл. nочта: milekhin@isp.nsc.ru
}

DOI 10.34077/RCSP2021-55

Сообщается об обнаружении комбинационного рассеяния света (КРС) двумерными, одномерными и нульмерными полупроводниковыми наноструктурами, усиленного металлизированным зондом атомного-силового микроскопа (ACM). При нанесении наноструктур на поверхность массивов золотых нанодисков обнаружено гигантское усиление сигнала КРС при нанометровом пространственном разрешении (нано-КРС).

Коллоидные сферические нанокристаллы CdSe и нанопластинки $\mathrm{CdSe} / \mathrm{CdS}$ типа ядро/оболочка были нанесены на поверхность массивов золотых нанодисков методом Ленгмюра-Блоджетт. Массивы золотых нанокластеров диаметром 50-200 нм были сформированы с помощью нанолитографии на поверхности $\mathrm{Si}$ и $\mathrm{Si} / \mathrm{SiO}_{2}$. Двумерные структуры, включая дисульфид молибдена $\left(\mathrm{MoS}_{2}\right)$ и графен, были нанесены на плазмонные структуры методом переноса. Одномерные наноструктуры представляли собой наноколонны AlN диаметром 200 нм, расположенные на поверхности золота.

Плазмонные свойства массивов нанокластеров $\mathrm{Au}$ на поверхности $\mathrm{Si}$ и $\mathrm{Si} / \mathrm{SiO}_{2}$ были изучены и определена зависимость энергии локализованного поверхностного плазмонного резонанса от структурных параметров нанокластеров.

Спектры нано-КРС были записаны на установке Horiba NanoRaman, состоящей из атомно-силового микроскопа AIST-NT, совмещенного со спектрометром KPC XploRA. Для возбуждения сигнала КРC использовались длины волн твердотельных лазеров 532, 638 и 785 нм. Для изменения спектров наноКРС использовались кантилеверы от Tipsnano (https://tipsnano.com/), покрытые слоем Au и Ag c помощью вакуумного испарения. В результате на острие иглы формировался единственный нанокластер металла размером около $80 \mathrm{Hм}$.

В спектрах нано-КРС двумерных и нульмерных наноструктур, расположенных на массивах нанокластеров $\mathrm{Au}$, обнаружены моды локализованных и поверхностных оптических фононов. Изображения нано-КРС массивов двумерных и нульмерных наноструктур представляют собой набор упорядоченных колец с диаметром, близким к размеру нанокластеров. Сравнение АСМ и нано-КРС изображений свидетельствует о том, что сигнал КРС от наноструктур наблюдается преимущественно для областей, расположенных вблизи граней нанокластеров Аu, где ожидается максимальное локальное электромагнитное поле. Показано, что усиление имеет электромагнитный характер, коэффициент усиления сигнала КРС достигает величины $10^{5}$, а пространственное разрешение- 2 нм.

$\mathrm{B}$ спектрах нано-КРС от наноколонн AlN доминируют моды поверхностных оптических фононов, что позволило выполнить КРС картирование отдельной наноколонны и получить информацию о локализации фононных мод с высоким пространственным разрешением.

Работа была выполнена при финансовой поддержке РФФИ (проект 19-52-12041). 